\title{
NEW CHINA WELCOMES NEUTRALITY
}

\author{
By Gerd Kaminski ${ }^{1}$
}

\section{The Objection at the Beginning:}

The People's Republic of China was opposed to welcoming neutrality in any of its forms ${ }^{2}$ at the beginning of the existence of the new Chinese-communist state. There were mainly two reasons for this Chinese attitude. Firstly: at that time China followed to a very large extent the line of the USSR ${ }^{3}$, in questions of upholding international peace and security and in questions of foreign policy as a whole. Right after the founding of the UN the USSR favoured a global system of collective security. This was incompatible with a positive attitude towards neutrality ${ }^{4}$. Secondly: there were genuine Chinese motives responsible for the fact that People's China could not regard "zhongli" (literally speaking - "standing in the middle") which means neutral, or even "yongjiu zhongli" (permanently standing in the middle) as something attractive. This explains why Mao Tse-tung had criticized such a policy in his writings. After having, a few times, on previous occasions hinted that neutrality does not go with his strategical conceptions ${ }^{5}$, he has been very outspoken about this problem in the first version of his famous article "On People's Democratic Dictatorship", which was published on June 30, 1949. He made it very clear that he would not let others remain in the middle without taking side:

"You are leaning to one side. Exactly. The forty years' experience of Sun Yat-sen and the twenty-eight years' experience of the Communist Party have taught us to lean to one side, and we are firmly convinced that in order to win victory and consolidate we must lean to one side. In the light of the experiences accumulated in these forty years and these twenty-eight years, all Chinese without exception must lean either to the side of imperialism or to the side of socialism. Sitting on the fence will not do, nor is there a third road. We oppose the Chiang Kai-shek reactionaries who lean to the side of imperialism, and we also oppose the illusions about a third road ${ }^{6}$."

\footnotetext{
1 Director of the Austrian Institute for China-Research, Lecturer on International Law at the Vienna University.

2 Permanent neutrality or Defacto Neutrality. The term Defacto Neutrality for the purpose of this study is applied extensively and covers Defacto Neutrality in the strict sense as well as the neutralism of the third force of non-aligned states. It is not easy to seperate clearly and satisfactorily Defacto Neutrality from neutralism. A possible approach would be to say that a defacto neutral state shows the same habit in international affairs as a permanently neutral state. That means it is prepared to safeguard itself against all kind of interventions from outside. It will stay away from the military blocs but apart from this impartiallity it will have its own outspoken ideological convictions and it will not hesitate to raise its voice and take sides if there is any international debate on these matters. A neutralist state is usually militarily weak, refuses to improve this situation of its national defence since it believes in its social and political means of preventing foreign interventions, it tries to escape from international confrontations by keeping away from the big pact-organizations and their ideologies. (See Rudolf L. Bindschedler, "Die Neutralität im modernen Völkerrecht", Zeitschrift für ausländisches öffentliches Recht und Völkerrecht, vol. 17, pp. 35-36 and the quotations there.

3 See Gerd Kaminski, "Neue Aspekte der chinesischen Haltung zum Gewaltverbot", China-Report, no 26/27, 1975/76, pp. $21-22$.

4 See Gerd Kaminski, “Bewaffnete Neutralität”, Vienna, 1971, p. 47.

5 See Gerd Kaminski, "Neutralität - eine Chance für die Staaten Südostasiens?", in: Weggel-FabritzekKaminski-Sichrovsky, "China und die Dominotheorie", Vienna, 1976, no 4, Berichte des Osterreichischen China-Forschungsinstitutes, p. 69 (no 4 of the Reports of the Austrian Institute for ChinaResearch).

6 "Selected Works of Mao Tse-tung", Peking, 1961, vol. IV, p. 415.
} 
The relevant section concludes in the first version:

"Not only in China but in the whole world one is either taking the side of Imperialism or Socialism. Neutrality is camouflage and there is no third way" !

Nevertheless it was still Mao Tse-Tung's flexible political style which enabled China not to stick to certain positions but - without giving up principles carry out rearrangements within the framework of foreign policy.

\section{Improvement on the Judgement of Neutrality by the Chinese People's Republic}

This improvement can again be explained by dualistic motives. An important role has been played within this development by the changing policy of the USSR since the mid-fifties. The USSR paid more attention towards neutrality and indicated that it had changed its former attitude in favour of a positive judgement ${ }^{8}$. There is evidence that the first positive link of the Chinese People's Republic with permanent neutrality is closely linked with the course and the interests of the USSR. This can be confirmed by citing from an editorial which was published on May 17,1955 in the Tientsin Da Gong Bao. You find an exact imitation of what we call the "Russian shinbone kick" against Adenauer and his NATO-scheme:

"The conditions that bring independence and freedom to Austria are also applicable in the case of Germany. There is every reason to believe that the German question can be settled quickly provided the Paris agreements are abrogated, and provided that Germany is not allowed to enter into any military treaty or have military bases set up in her territory ${ }^{9} "$.

Yet one should not forget to mention that there were reasons for China to welcome Austrian neutrality which complyed not only with Russian but also with Chinese interests. The above mentioned $\mathrm{Da}$ Gong Bao from Tientsin reported that Austria's keeping clear from all military alliances has been in her own national interests:

"The fact that Austria had promised not to join any military bloc ... was in full conformity with her national interests. This entitles her to the happy prospect of long-term peaceful development. Her national independence is to be maintained. She is in a position to establish peaceful economic and political relations with all countries ${ }^{10}$."

This means that China regarded, - without reference to the German question, the permanently neutral status as an attractive solution in international politics and thus was also looking after her own national advantages. Especially in her own surrounding where China was facing an encirclement by SEATO-states China was keen on weakening the grip of this military alliance by propagating neutrality to its members as the non-participation in military alliances is one of the most important presuppositions for neutrality. Naturally, the call to other Asian states for managing their foreign and especially their security affairs independently became one of the favourite topics of Chou-En-Lai's speeches and talks at the Bandung-Conference in $1955^{11}$ and what was behind then he has himself explained

\footnotetext{
7 See Mao Tse-tung, “Uber die Diktatur der Volksdemokratie”, Verlag für fremdsprachige Literatur, Peking, 1950, pp. 9-10. - I owe much gratitude to Mr. George Wächter who bought this pamphlet in

8 See Gerhard Hafner, "Die permanente Neutralität in der sowjetischen Völkerrechtslehre - Eine Analyse", Osterreichische Zeitschrift für öffentliches Recht, vol. 19, 1969, p. 215.

9 Quoted in: People's China, no 12, June 16th 1955, p. 41.

10 Ibid.

11 Horst Sasse, "Die asiatisch-afrikanischen Staaten auf der Bandung-Konferenz", Frankfurt-Berlin, 1958, pp. 52, pp. 62.
} 
at the Third Session of the National People's Congress on June 28, 1956 by stressing the fact that more and more countries would oppose the tensions created by the military blocs and that even states of the US-controlled military blocs would show an increasing tendency to get rid of that control and to change to a neutral course ${ }^{12}$.

\section{The Chinese Standard of Information about Neutrality in $\mathbf{1 9 5 5}$}

In spite of the increased attention given to the concept of neutrality in all of its forms in the mid-fifties, China's standard of information about the legal aspects of Neutrality has been comparatively modest. This is proved by an article on "Neutral States" which was published in the Chinese magazine "World Knowledge" on June 20, $1955^{13}$.

Even if one concedes, as an indication for a minimum-standard of information about Neutrality, that the author Dong Zheng distinguishes correctly in his article between temporary and permanent Neutrality, one cannot overlook at few mistakes contained in the part dedicated to Permanent Neutrality. Dong Zheng writes erroneously about the conclusion of treaties as a legal basis for the creation of Permanent Neutrality, and does not mention at all the unilateral notification, which subsequently gains recognition and thereby is giving the same legal effect. One could excuse him for his wrong statement that the Permanent Neutrality of Belgium has been annulled by the Paris Peace Conference ${ }^{14}$, but it is rather surprising that in spite of the attention paid by China to Austria's Permanent Neutrality, he believed that this special legal status had been created by the Vienna "Staatsvertrag".

Nevertheless, the assertion of the author has to be stressed that: "To moderate the tensed international situation and to increase the influence of peace, the nature and significance of neutral states have gained a new meaning ${ }^{15}$."

Consequently China did not hesitate to admit to its instruments of foreign policy the support of Neutrality.

\section{The Development of the Chinese Attitude towards Neutrality till the Early Sixties (early 1960s)}

\section{(A) Defacto Neutrality:}

China soon came to pay special attention to Defacto Neutrality. Not much later she made it clear that she expected from these states - like the USSR - not just neutrality but "positive" neutrality. That meant these states were to support the progressive camp not in the form of an alliance but by other ways in order to express their sympathy.

\footnotetext{
12 Chou En-lai, "On Present International Situation - China's Foreign Policy and the Liberation of Taiwan" (Deliverd at the Third Session of the First National People's Congress on June 28, 1956), Foreign Languages Press, Peking, 1956, $\mathrm{p}_{3}{ }^{3}$.

13 See Dong Zheng, "Zhongli guo", Shijie Żhishi ("Neutral States", World Knowledge), no 12/6 pp. 32-33.

14 See Gerd Kaminski, "Der Neutrale als Aggressionsziel - Voraussetzungen und Folgen des Angriffs auf einen dauernd neutralen Staat, demonstriert am Beispiel Belgiens", Vienna, 1975, pp. 57-65.
} 
This can be demonstrated by citing an article from Peking's Renmin Ribao (People's Daily) published in the issue of February 25, 1961. This article deals in one paragraph with the US-supported proposal of the king of Laos that a "good-will mission" consisting of the neutral states namely Cambodia, Malaya and Burma should try to negotiate a cease-fire in Laos ${ }^{16}$. The Chinese comment shows that, not all states being neutral according to traditional criteria, were neutral in the Chinese sense.

"The United States publicizes these three nations as all peaceful and neutral nations. In the words of the declaration of the Laotian King, their impartiality in the sphere of foreign affairs' and their 'devotion to the cause of universal peace are recognised and respected by all countries'. These words are undoubtedly correct as applied to Cambodia and Burma. These two countries, in their foreign policies, have consistently pursued a peaceful and neutral policy and have always supported the peace and neutrality of Laos. The Chinese Government and people strongly endorse this policy and position of Burma and Cambodia. However, Malaya can hardly be regarded as a state strictly abiding by a peaceful and neutral policy. Although it has not joined the Manila military bloc, it has consistently followed the line of the Western countries in international affairs. As is generally known, Malaya took the lead initiating in the United Nations a resolution on the question of Tibet a resolution which interferes in the internal affairs of China. Furthermore, it has recently been preparing to organise a so-called 'Association of Southeast Asian Nations' with Thailand and the Philippines - member nations of the Manila military bloc. From this it is clear that the US proposal to bring Cambodia and Burma together in a commission with Malaya is by no means an indication of respect for truly peaceful and neutral nations." (Peking Review $)^{17}$

By hinting that Malaya, although not being a member of any military bloc, still cannot be regarded neutral because of its pro-western foreign policy, China employed Soviet-developed theories on Neutrality. According to these theories, a neutral state cannot restrict itself just to remain outside of the military alliances, but for the sake of being fully recognised as a neutral, it has to: -

a) Participate actively in the fight for the consolidation of peace (positive neutrality $)^{18}$

b) Abstain from taking side ideologically (in other words from implementing western concepts within the framework of its foreign policy) - a form of "ideological neutrality"

These Soviet theories have until now failed in worming their way into the system of legally binding rules of traditional neutrality-law. Nevertheless, China considered them useful and adapted them by and by to Chinese requirements.

The active participation in the fight for the consolidation of peace got, in the Chinese conception, a strong accent of an alliance of mainly Asian and African states - the Third World - against colonialism and imperialism. By and by corresponding to the worsening of Soviet-Chinese relations - the weight in the

15 See Dong Zheng, loc. cit., p. 33.

16 Translation of this editorial in Peking Review, no 9, March 3, 1961, p. 6.

17 Ibid., pp. 6-7.

18 B. V. Ganjuskin, “Nejtralitet i neprisoedinenie”, Moscow 1965, S. 10 quoted from Hafner, loc. cit., p. 222. 
alliance of socialist and countries of the third world shifted. The Soviet "revisionists" had lost their significance in that alliance, and China remoulded it into a Chinese alliance with other developing countries. Its spearhead was still mainly directed against the US but slowly was also turned against the USSR which was prevented by location and stage of development for finding admittance among the group of Asian-African developing states.

The Afro-Asian accent in connection with Neutrality and non-alignment has been very clearly emphasized by Chou En-Lai when he talked on December 20, 1963 to a correspondent of "Middle East News" in Cairo. The question was:

"What are Your Excellency's views on the role of the non-aligned nations in the international sphere? Is China, a big power, willing to help the nonaligned states, thereby helping them to maintain their policy of neutrality and non-alignment?

answer:

A true non-alignment policy means non-participation in military blocs of an aggressive character in any form, and opposition to the imperialist policies of aggression. Many Asian and African-countries follow such a policy and are thus playing a great positive role in strengthening Afro-Asian solidarity, combating aggression and intervention by old and new colonialists and safeguarding world peace.

The imperialists energetically oppose Asian and African countries following a true non-alignment policy of peace and neutrality. An obvious examples is the recent intensified US intervention in and pressure on Cambodia.

The Chinese Government and people have all along fully respected the nonalignment policy of peace and neutrality pursued by Asian and African countries. They support and help those countries in their just struggle against imperialist aggression and intervention ${ }^{19}$."

From this quotation two conclusions can be deducted: 1 . It is obvious that Chou En-Lai, although the question about the neutral policy of non-aligned countries has had quite a general formulation in his answer, has added a very strong scent of Afro-Asian solidarity. 2. That China's position towards Defacto Neutrality which had been presented by Chou himself at Bandung (then it being content that states gave up their membership in western military alliances in favour of an unclassified foreign policy outside of the military bloc) was not more up to date. The Chinese catalogue of demands towards these states was increasing.

\section{(B) Permanent Neutrality:}

The first engagement of Chinese politicians with the problem of proper Permanent Neutrality was caused by Austria's declaration of neutrality. Chou En-Lai declared at the Second National Committee of the People's Political Consultative Conference of China on January 30, 1956.

\footnotetext{
19 "Afro-Asian Solidarity Against Imperialism", - A collection of documents, speeches and press interviews from the visits of Chinese leaders to thirteen African and Asian countries, Foreign Languages Press, Peking, 1964, p. 32.

Attention should be also paid to the significant title of this collection.
} 
"Austria's decision to maintain Permanent Neutrality has paved the way for Austria's peaceful development. We respect Austria's neutral status and would like to see the establishment of relations of peaceful cooperation between China and Austria ${ }^{20 . "}$

Beyond doubt these were very friendly words for another state's status of Permanent Neutrality. On the other hand, at that time the fate of Austria did not involve important Chinese interests and, therefore, one has to look to Laos for getting a more thorough impression of the Chinese attitude towards Permanent Neutrality during that period of time.

Immediately after the first Laos Conference in 1954, China had shown sympathy to the neutralist course of the Laotian Coalition Government. After the removal of this Government by a rightist coup d'etat which happened not quite without American assistance, there were indications of great Chinese irritation and China spoke strongly against foreign intervention in that area ${ }^{21}$. Only after interference by others into Laotian inner affairs did China start to grant effective aid to the communist Pathet Lao. Therefore foreign politicians and experts have inclined to certify that China between the two Laos Conferences respected the (at that time not internationally legal established) neutrality of Laos and did not violate the Geneva Agreement'22. At the newly convened Laos Conference in Geneva 1961/62 the following Chinese viewpoints were stressed:

\section{a) General Items:}

1. The exact defining of the neutrals rights and duties in order to prevent abuse of its legal status.

2. The securance of complete independence of the permanent neutral state and its duty to abstain from all kind of activities which could lend a hand to foreign intervention ${ }^{23}$.

3. No protection from outside and no foreign interference with the management of the national defence by the neutral state itself ${ }^{24}$.

20 China-Report no 26/27, 1975/76, p. 45.

21 See Arthur Dommen, "Conflict in Laos - The Politics of Neutralization", New York - Washington London, 1971, pp. 136-137; Gerd Kaminski, "Neutralität - eine Chance für die Staaten Südostasiens?",

22 F. 15- 16. Senate Majority Leader Mike Mansfield in his 1968 Report quoted by James Chieh Hsiung, "Law and Policy in China's Foreign Relations", New York - London, 1972, p. 301; Oskar Weggel, "Heimweh nach der fernen Neutralität - China und Laos", China aktuell, no 2, March 1973.

23 The chinese caution went so far to insist on a paragraph in the Laotian Neutrality-Declaration (Art. 7). Which has the purpose of preventing Laos from accepting development-aid under conditions which could endanger the independent management of Laotian inner affairs.

24 Extracts from Foreign Minister Chen Yi's Speech on June 26, 1961: “. . Now I want to bring up another point. Under these supplementary articles, the United States wants not only to obtain all the national defence secrets of Laos through the international commission, but also to fix the strength of the army of Laos and the quantities and types of its armaments. As we all know, a country's national defence needs can only be determined by the government of that country itself; it is the minimum indication of national sovereignty. The United States has indeed made a preposterous demand. If this is not undisguised interference in Laotian internal affairs, then what is it? When a country voluntarily pursues a policy of peace and neutrality, it does not mean that the country should be demilitarized or that its national defence should be placed under international control. It is absolutely impermissible to impose on Laos such articles which could only apply to vanquished nations...

All of us seem to agree that there is no need for international control over a country's voluntary pursuance of a policy of peace and neutrality. But the delegates of some countries have further expressed the view that Laos is a special case which requires international control. In the words of $\mathrm{Mr}$. MacDonald "The Government of Laos, however sovereign, will hardly be powerful enough by itself to guarantee its neutrality in the tense aftermath of recent events", so Laotian neutrality requires socalled "protection" ...

This "theory of protection" - protection of sovereignty, of neutrality and of independence - is ne novelty. To cite a recent example, the SEATO bloc has treated LAOS as its "protected area".

$\ldots$ Everyone can see that this is an attempt to forcibly occupy the house in the name of protection ... Since Laos is recognized as a sovereign nation, it must be recognized too that the Laotian Government alone has the right to determine the quantities and types of weapons it requires for self-defence and the quarters from which these weapons will be bought. - Peking Review, no 26/27, July 7, 1961, 
b) Special Items (influenced by the fact Chinese-Laotian neighbourhood):

1. The obligation of Laos to keep friendly relations with all states especially the neighbours states (that means China) ${ }^{25}$. A mixture of a reduced "positive neutrality" and reminiscences of the old East and Southeast-Asian system protected by China.

2. The conception that especially Southeast Asia should be turned into an area free from military blocs. These countries could count on Chinese support for their "just cause of practising a policy of peace and neutrality, safeguarding national independence and opposing interference and aggression from outside" (Chen $\mathrm{Yi}$ at the opening session of the Geneva Conference on May 16,1961$)^{26}$.

As a general line of Chinese attitude towards permanent neutrality can be deducted that China believed in permanent neutrality as a feasable instrument for the reduction of international tension. This can be seen from the detailed concept worked out by the Chinese as well from Chen Yi's hint that China would be glad to see this status spread out among the Southeast Asian states. It should be also stressed that China has showed considerable restraint in applying the principle of "poitive neutrality" in the case of permanently neutral Laos. Friendly relations, but not militant anti-imperialist solidarity were expected.

\section{Enlargement of the Catalogue of Chinese Demands towards the Neutral during the Sixties (1960s)}

\section{(A) Defacto Neutrality:}

The deteroriation of Sino-Soviet relations especially in connection with the correct line on war and peace respectively on peaceful coexistence has exercised strong influence on the Chinese attitude towards defacto neutral status. Save their absence from military alliances, these states were expected to be fullfledged fraternal fighters in the cause of anti-colonialist and anti-imperialist struggle. This can be proved by recalling the attacks directed at that time by China against nonaligned Yugoslavia. A commentary of Renmin Ribao published on May 10, 1963 on the occasion of the new Yugoslavia Constitution stated:

"The foreign policy of Yugoslavia as defined in the new Constitution sheds a luminous light on the true colours of the Tito group as running dogs of US imperialism. In their new Constitution, under the sign-board of so-called peaceful coexistence and active cooperation, the Tito group negate altogether class struggle in the international arena, negate the antagonism between the socialist camp and the imperialist camp, negate the antagonism between the oppressed nations on the one hand and imperialism and colonialism on the other ${ }^{27}$."

The principle that the antagonism between socialist and imperialist and between oppressor and suppressed states has to be mainly taken into account - also within

25 Art. 1 of Neutrality Declaration

26 Peking Review, no 20, May 19, 1961, p. 7

27 Peking Review, no 20, May 17, 1963, p. 12; see also Mao Guang Sheng. Die Angst der ChruschtschowRevisionisten vor Widersprüchen, in: Hongqi, no 8, July 31, 1965, in: SCMM, no 487, pp. 17-25. 
the framework of the neutral policy of non-aligned countries. It was also stressed at the time when the Chinese encouraged by the Indonesian CP, cited it (the principle) with much satisfaction in the Peking Review ${ }^{28}$.

"Now it is even clearer why at the 'summit conference of non-aligned countries' in Belgrade there existed such a serious opposition of ideas between participants in the conference on the one hand and the 'farsightedness' of Yugoslavia and India on the other. So 'far-sighted' are the revisionists that they no longer hate imperialism, no longer oppose imperialism and even defend the imperialists by protecting them from attacks (as President Sukarno put it) by the people of various countries who are 'irresponsible and shortsighted'."

In other words: the Chinese model for Defacto Neutrality turned during the sixties into demanding the unconditional efforts of the neutrals in anti-imperialist struggle. The request for refraining from membership in military blocs raised by Chou En-Lai at Bandung had turned into the demand to refrain from standing passively in the middle of the turmoil of anti-imperialist fighting. Where China found it possible - that means first of all in her own local sphere of influence she has shown herself not content with this theoretical approach but tried to make the defacto neutrals put this model into practice. This can be demonstrated by the example of Sino-Burmese relations.

China wanted to form an Afro-Asian unified front against the US-bombing of Northern Vietnam and did not exempt defacto neutral Burma from participation. Consequently, Liu Shao-chi then the Chairman of the PRC told $\mathrm{Ne}$ Win at a Banquet in Peking on July 24, 1965:

"Since we set great value on the friendship of both our peoples and the interests of solidarity against imperialism we can always solve questions arising between us successfully in an amical way ${ }^{29}$." Yet just this question turned out to be of a kind which could not be settled amically between the two states. Ne Win in his answer mentioned only in a very general way about common efforts for the upholding of world peace and carefully ommitted any hint in the direction of the expected militant anti-imperialist solidarity ${ }^{30}$. China was not satisfied with this attitude and, moreover, believed to see pro-American tendencies in Burma's foreign policy. The Chinese reaction consisted in considerable support for the communist revolutionary movement (White Flag) in Burma.

1967, at the hightide of the Cultural Revolution, Peking Rundschau (German version of Peking Review) published on its first page a resolution of the Burmese $\mathrm{CC}$ containing the following paragraph:

"We proletarian revolutionaries of Burma must also participate actively in the Great Proletarian Cultural Revolution of China and stand on the side of the Chinese proletarian revolutionaries; by no means must we remain neutral, because the enemies of China's Great Proletarian Cultural Revolution are also our enemies ${ }^{31}$."

\footnotetext{
28 Ibidem, p. 14.

About the earlier gradual development of this Chinese attitude towards the defacto neutral countries see A. M. Halpern, “The Chinese Communist Line on Neutralism”, China Quarterly, 1961, pp. 97-99.

29 Peking Rundschau, no 31 , August 3, 1965, p. 8.

30 Ibid.

31 Peking Rundschau, no 51, December 18, 1967, p. 6.
} 
The publication of this resolution in Peking can be interpreted as a Chinese identification with the views presented there and it need not be mentioned that they are incompatible with the respect of another state's Defacto Neutrality.

The Chinese conduct after the beginning of the sixties and especially during the time of the Cultural Revolution towards defacto neutrals therefore is in a nutshell this: Chinese demands at that time piled up so highly that to meet all of them there would not have been room for a truly neutral policy of the other state. This point can be considered as a weakening of the idea of Defacto Neutrality in the concept of Chinese foreign policy of that time.

\section{(B) Permanent Neutrality:}

The People's Republic of China has become well known for the fact that she is acting rather scrupulously and prudently in those cases where she entered legally binding commitments ${ }^{32}$.

In accordance with this principle of her international conduct, China has exempted Laos from any kind of unlawful pressure even during the time of the Cultural Revolution ${ }^{33}$. During the sixties China never ceised to protest against foreign intervention in Laos and at the same time kept to her positive approach towards Laotian Permanent Neutrality. Consequently she gave a very warm welcome to a negotiation programme of the Laotian leftists which was released on March 6, 1970 and demanded "strict neutrality" for their state ${ }^{34}$.

The unchanged positive Chinese attitude in respect of Permanent Neutrality can also be demonstrated by using the example of Cambodia. During the sixties Prince Sihanouk repeatedly tried to secure the position of his country by entering the status of Permanent Neutrality and getting the guarantee of the big powers. China has been willing to participate in the creation of a permanently neutral Cambodia ${ }^{35}$. This project was turned down not because of Chinese but rather owing to US-reservations ${ }^{36}$.

Balancing the books of China's behaviour towards Permanent Neutrality since the beginning of the sixties brings the result of an unchanged positive Chinese conduct.

\section{Modification of the Theoretical Basis in Favour of Neutrality during the Sixties}

A global assessment judging Chinese attitudes during the sixties towards Defacto and Permanent Neutrality together shows a development of the account into the red. On the other hand, it can be regarded of great importance and support for a later more positive Chinese attitude towards Neutrality that it was just during the sixties when a change in the theoretical basis for judging neutrality became visible to the outside world. It became visible by a modified version of Mao Tsetung's article "On the People's Democratic Dictatorship" which was published in September 1960 in the fourth volume of the Chinese edition of the "Selected

32 Compare Luke T. Lee, "China and International Agreements", Leyden 1969.

33 See 22.

34 See Oskar Weggel, "Heimweh nach der fernen Neutralität", pp. 65-66.

35 See "Erklärung der chinesischen Regierung: Unterstützung für die drei Bedingungen Kambodschas für die Abhaltung einer internationalen Konferenz", Peking Rundschau, no 19, May 11, 1965, pp. 13-14.

36 See Oskar Weggel, "Strategische Freunde - taktische Feinde - China und Kambodscha", China aktuell, no 3, April 1973, p. 142. 
Works of Mao Tse-Tung” and soon afterwards appeared in April 1961 in an English edition. The English edition and the other editions in foreign languages ${ }^{37}$, show one decisive difference in Mao Tse-tung's writing about Neutrality. Of course he still holds the position that Neutrality is not acceptable as a course for the Chinese people and we, therefore, can find the sentence unaltered: "... In the light of experiences accumulated in these forty years and these twenty-eight years, all the Chinese without exception must lean either to the side of imperialism or to the side of socialism. Sitting on the fence will not do, nor is there a third road. We oppose the Chiang Kai-Shek reactionaries who lean to the side of imperialism, and we also oppose the illusions about a third road ${ }^{38}$."

Well, as far the Chinese people are concerned there is no doubt about Mao Tse-tung's opinion. But, and so far I know, this is stressed in this article for the first time, if one compares this version with the version of 1950 cited before, one comes to the conclusion that Mao Tse-tung is not longer absolutely rejecting Neutrality as a possible way for others. This conclusion can be based on the fact that the analogy drawn by Mao Tse-tung from China's position to the general situation in the whole world has been ommitted. We miss the sentence which follows in the earlier version:

"Not only in China but in the whole world one is either taking side for imperialism or socialism. Neutrality is camouflage and there is no third way ${ }^{39}$."

Even though Chinese foreign policy especially during the time of the Cultural Revolution transgressed this theoretical basis and has raised more demands in relation with the neutrals as would have been necessary in regard of Mao Tsetung writings, one should not however forget to stress the importance of the fact that during the sixties theoretical preconditions were laid which enabled the decision makers of Chinese foreign policy later on to steer a positive and more relaxed course towards the neutrals without colliding with principles contained in Mao Tse-tung's writings.

\section{The Period Since the End of Cultural Revolution:}

\section{(A) The Global Concept of Chinese Foreign Policy:}

Since the end of the sixties and the beginning of the seventies one can notice both the consolidation of and a resumption in activity in the field of Chinese foreign policy. This has to be viewed in relation to intensification of the Sino-Soviet conflict: the armed clashes on the Sino-Soviet border in 1969 and the invasion of Czechoslovakia by troops of the Warsaw-Pact in 1968.

These experiences have helped to create the following "leitmotifs" of Chinese foreign policy:

a) A front against the superpowers especially against the USSR (See Chou's report on the 10th CPC-Congress, 1973) including tendencies of expanding this front over the limit of Afro-Asian states by embracing also the states of

37 See f. i. vol. 4 of the German version, Peking 1969, p. 442.

38 "Selected Works of Mao Tse-tung", Peking, 1961, vol. IV, p. 415.

39 See under 7. 
the "Second World" (see the speech of Chinese foreign minister Qiao GuanHua at the UN-General Assembly in 1975)

b) Propagation of the priority of independence and sovereignty and the equality of all states. (can be seen already very clearly in Lin Piao's report to the 9th CPC-Congress 1969)

The leitmotifs have not failed to exercise influence on the Chinese attitude towards neutral states.

\section{(B) The Chinese Standard of Information about Neutrality in 1972}

The above mentioned principles of Chinese foreign policy made the Chinese legal experts emphasize strongly the sovereignty and independence of neutral states.

This has been the clear result of interviews granted to the author of this study in April 1972 by the Director of the Bureau for International Law at the Chinese Ministry of Foreign Affairs Shen Wei-liang and his legal advisers, Lin Qing and Huang Jia-Hua. Nearly all questions concerning problems in connection with the international behaviour of the permanent neutral state were answered by them in a stereotype way: "This has to be decided by the neutral state itself."

This answer was also given in response to the following important question:

"Is a state still a permanent neutral state after its Neutrality has been severely violated?"

"Has a permanently neutral state to join sanctions undertaken by the UN?" ("If it wants to participate its wish will be respected but we would not demand his participation.")

"What precautions have to be taken by a permanently neutral state for safeguarding his neutral status?”

Although all of these questions are of great importance not only for the permanent neutral states but also for the big powers who usually fear infringements of their rights in respect of the neutrals, the Chinese experts have abstained from formulating any Chinese demands but left all this for the sovereign decision of the permanent neutral state itself.

Moreover I (author) could note down during the above-mentioned interview the following statement of the Chinese side which is of essential interest for the neutral states. On the question of ideological Neutrality, the Chinese experts responded by stating that:

"It is very difficult to attain absolute neutrality and besides it is not permitted to limit unlawfully the rights of a neutral state."

Also in this case the global concept of Chinese foreign policy demanding that the sovereignty and independence, especially of the middle-sized and small states, should be respected prevailed over the interest of keeping the neutrals under a more tight control.

Thus, the Chinese experts have proved to have much better legal understanding about the problems of Permanent Neutrality than shown by the author of the above cited article dated 1955. In contrast to him, they (the Chinese foreign ministry officials) have been well aware that permanent neutrality cannot only be created by treaty but also by notification and recognition. They asserted that by recognising Austria's Permanent Neutrality in 1971 in the Joint Chinese-Austrian Communique about recognition and establishing diplomatic relations China has 
committed herself legally not to violate the neutral status of Austria and this has to be executed in the strictest way. In this connection, the Chinese side distinguished very clearly between the non-legally binding programmatic declaration on Austrian neutrality by Chou En-Lai at the People's Political Consultative Conference in 1956 and the legally binding recognition of Austrian neutrality in 1971.

The increased information about Neutrality and the favourable answers about sovereignty and freedom of action for the neutrals indicate a line of Chinese practice which seemed to be very agreeable for the neutrals. In fact this can be concluded from the Chinese practice towards neutrals since the beginning of the seventies - a subject which will be examined in the following paragraphs:

\section{(C) The Chinese Attitude towards Defacto Neutral States since the Beginning of the Seventies:}

Of course China also nowadays applauds if a defacto neutral state agrees to take part in the struggle against oppression. This oppression formerly termed the Imperialist Camp headed by the US, of late however the oppression of the hegemonism of the two superpowers. Between the two the Soviet-Union is the more dangerous one and has to be more strongly resisted. Though China does not force defacto neutrals into any kind of alliance, China however praises the antihegemonial attitude of defacto neutrals so highly that one can realise what is China's model defacto neutral state ${ }^{40}$. The indirect signalling of China in the direction of the nati-hegemonial alliance without applying pressure becomes especially clear if one considers that China even praised such weak states like Malta or San Marino for their brave fight against aggression and hegemonialism 41,42 .

(D) The Chinese attitude towards Permanent Neutral States since the Beginning of the Seventies:

China's good record of lawful and positive international behaviour towards permanent neutral states found its continuance during the seventies.

On March 10, 1971 there started negotiations in Bucarest with "permanent neutral Austria" about the recognition of the Peking Government by Austria and after meeting for only five times the Communique was signed on May 26, 1971 combining the issues of the establishment of diplomatic relations between the two countries and the recognition of Austrian's Permanent Neutrality ${ }^{43}$. In a Press Conference on May 27, 1971 the Austrian Foreign Minister Dr. Kirchschläger declared that China had shown much willingness in giving its recognition of the Permanent Neutral status of Austria. He added that Austria had not to urge China in this regard and also it (Austria) did not have to make any concessions in return ${ }^{44}$. Since that time China had on several occasions indicated that it is supporting Austrian Permanent Neutrality.

\footnotetext{
40 See f. i. Peking Rundschau, no 14, April 8, 1975, p. 14 (Mexico); no 21, May 28, 1974 (Cyprus); no 29, July 23, 1974, p. 5 (Tunesia); no 46, November 19, 1974, p. 5 (Trinidad and Tobago); no 9, March 5 , 1974 (Zambia); no 13, April 3, 1973, p. 6 (Cameroon); no 26, July 3, p. 7 (Mali); no 19, May 14, 1974, p. 14 (Senegal); no 36, September 10, 1974 p. 7 (Togo); no 51 December 24, 1974, p. 7 (Zaire).

41 China im Bild, no 3, 1975 , p. 9.

42 Peking Rundschau, no 42, Oct. 24, 1972, p. 3.

43 See Gerd Kaminski, "Zur Anerkennung der Pekinger Regierung durch Osterreich", Juristische Blätter, no 5/6, March 11, 1972, pp. 135-139; idem, "Rechtliche und politische Aspekte der Anerkennung der Pekinger Regierung durch Osterreich", China-Report, no 1, 1971, pp. 5-11. 44 Wiener Zeitung, May 28, 1971, p. 2.
} 
On the occasion of the Chinese National Day Celebration in 1971 the Chinese Ambassador to Austria Wang Yue-Yi said in his speech:

"The Chinese Government and the Chinese people are supporting the Austrian people in its just struggle for safeguarding its country's independence and neutrality ... In the Joint Communique on the establishment of diplomatic relations between China and Austria special reference is made that 'The Chinese Government respects the Republic of Austria's status of neutrality'. 'The Austrian Government recognises the Government of the People's Republic of China's sole legitimate Government'. This indicates that the friendly relations between China and Austria have already entered a new stage $\ldots .^{45}$."

In October 26, 1972 the Chinese Foreign Minister Chi Peng-Fei included in his speech at the Austrian Embassy on the occasion of the Austrian National Day the following statement:

"Austria, situated in the heart of Europe, is a country with a long history and cultural tradition. After World War II, the industrious and talented Austrian people rapidly healed the war wounds and rehabilited and developed their national country. In 1955 in accordance with their own will, they chose the road of permanent neutrality.

The Chinese Government has consistently supported the Austrian people in their efforts to safeguard national independence and state sovereignty. As early as January 1956, Premier Chou En-lai officially stated, on behalf of the Chinese Government, that we respect Austria's neutral status. The Chinese Government reaffirmed this position last year in the Joint Communique on the establishment of diplomatic relations between our two countries. The Chinese Government always holds that all nations, big or small, should be equal. The internal affairs of a given country must be handled by that country and no other country has the right to interfere.$^{46}$."

Similar positive statements have followed since that time by Vice-Premier for Foreign Trade, Bai Xiang-Guo in October, 1972 at a Banquet in honour of the Austrian Minister for Trade and Commerce Josef Staribacher ${ }^{47}$; Vice-Premier Deng Xiao-ping at a meeting with a delegation of the Austrian Institure for China-Research in September 197348; Chinese Foreign Minister Chi Peng-fei at a Banquet in honour of Austrian Foreign Minister Dr. Kirchschläger in April 197449 and Chinese Foreign Minister Qiao Guan-hua at a meeting with a delegation of the Austrian Institute for China-Research in April, $1975^{50}$.

Most recently also Austria has been reminded of the support of its Permanent Neutrality by the Chinese on the occasion of Premier Chou En-Lai's death. On January 21, 1976 the Chinese Embassy in Vienna sent out to a number of Austrian people an excerpt of Chou En-Lai's report to the People's Political Consultative Conference where Chou made positive reference to Austrian Permanent Neutrality.

Besides these verbal assertions China has also shown sympathy for permanent neutral Austria by other ways. Austria's trade with China was able to increase

45 China-Report, no 2, 1971, p. 25.

46 China-Report, no 7/8, 1972 , p. 37.

47 Peking Rundschau, no 44, November 7, 1972, p. 5.

49 Peking Rundschau, no 15, April 16, 1974, p. 5. Mit Konsequenz und Härte, Freiheit, no 4, April 1975, p. 37. 
considerably ${ }^{51}$; Austria was among the first states to be allowed to hold an industrial exhibition in China; among the first permitted to send doctors for Acupuncture studies; one of the few countries to host the great Chinese archeological exhibition and one of the very few invited to send an Orchestra to China ${ }^{52}$.

Thus the record of China's attitude towards permanent neutral Austria merits consideration. Moreover, the citation of Foreign Minister Kirchschlägers statement to the Chinese journalist's delegation in February, 1972 which has been included into the report of that delegation, has kept its full validity: "Austria highly evaluates China's respect for her neutral status, as stated in the communique. This is of great significance to us (Austria) 53." $^{3}$

A similar friendly attitude towards Permanent Neutrality has been manifested towards Laos. Chinese Government has showed much satisfaction when the hostile fractions in Laos came to an Agreement on February, 21, 1973. In editorials of Renmin Ribao from February 23, and September 16, this Agreement has been praised and, moreover, hope has been expressed that this Agreement would serve to secure for Laos the path of Neutrality ${ }^{54}$.

Even at a time when the Pathet Lao defacto has been in power in Laos, China did not stop to sympathize Laotian Permanent Neutrality. On the occasion of the Lao Independence Day, the Renmin Ribao on October 12, 1975 carried an editorial which reads in part as follows:

"We are convinced that the heroic Lao people, carrying forward the war-time revolutionary spirit, adhering to the principle of independence and selfreliance will certainly overcome all difficulties on their road of advance and build a peaceful, independent, neutral, democratic, unified an prosperous Laos ${ }^{55}$."

One may interpret this as an explosive Chinese attempt to confront the Soviet System of communist satellites with a Chinese anti-model of permanent or defacto communist states (around that time China has also applauded the neutral course of communist Cambodia) $)^{56}$. Their neutral status would protect this states from intervention by big communist powers by way of abusing proletarian internationalism.

China has also shown much interest to expand this belt of permanent neutral or at least defacto neutral states also in her farther neighbourhood, that means to the whole area of South Asia. She has paid more and more attention to the plan for the Neutralisation of Southeast Asia since the time of its acceptance by the Foreign Minister Conference of ASEAN (consisting of Indonesia, Malaysea, the Philippines, Singapore and Thailand) in Kuala Lumpur on November 27, 1971. This can be proved by Qiao Guan-hua's speeches at the UN General Assembly. In 1973 there has been only indirect reference to those Neutralisation plans by stating that nobody should strive for hegemony in the Asiatic-Pacific area and by criticising

\footnotetext{
51 Peter Jehly, “Osterreichs Außenhandel mit der Volksrepublik China”, China-Report no 24/25, 1975, p. 26

52 Gerd Kaminski, “Chinesische Positionen zum Völkerrecht”, Berlin, 1973, p. 306.

53 New Friendship between Chinese and Austrian People" (by Chinese Journalist's Delegation), China Report, no 6, 1972, p. 17.

54 Peking Rundschau, no 8, February 27, 1973, pp. 8-9; no 38, September 25, 1973, pp. 8-9.

55 Hsinhua (London), Weekly issue 349 , October 16, 1975, p. 14.

56 Peking Rundschau, no 34, August 26, 1975, p. 7.
} 
the Soviet propagated concept for a collective security system for Asia ${ }^{57}$. In 1974 the Chinese positive attitude to the plans of ASEAN has been already more visibly expressed by presenting the view that the tendency of Southeast Asian countries to liberate themselves from intervention and big power rivalry is growing day by day58. In 1975 we find an expressis verbis welcome for the plans for the Neutralisation of Southeast Asia: “... The demand of the Southeast Asian countries to turn their region into one of peace, liberty and neutrality, free from intervention of whatever form and kind, finds recognition and regard by an increasing number of countries ${ }^{59}$."

Also in bilateral contact, China started around 1975 to stress her support for the Neutralisation of Southeast Asia ${ }^{\mathbf{0}}$.

Altogether this facts seem to permit to draw the conclusion that the concept of Permanent Neutrality has gained more sympathy in China during the seventiea. This is not only proved by the positive Chinese behaviour towards states which are already permanently neutral but also by the evidence of Chinese interest of turning her nearer and farther neighbourhood into a zone of permanent neutrality. The Chinese practice of the sixties towards permanent neutral states has laid already a basis for this kind of development. But it is beyond doubt that this development has been supported and accelerated by the sharpening of the SovietChinese confrontation policy and the Chinese fear of a Soviet encirclement policy by filling up strategic positions left by the US-retreat from Southeast Asia.

\section{Most Recent Development and Outlook:}

\section{(A) More Revolutionary Accent of Recent Chinese Foreign Policy:}

During the last months indications have been accumulating that China might again switch to a certain extent to a more revolutionary accentuated foreign policy. This might be proved not only by Qiao Guan-hua's last speech at the 30th General Assembly Session of the UN where he stressed, more than usual the armed fight against oppression ${ }^{61}$, by the last two sentences of Mao Tse-tung's poem "The birds" Conversation" published in January 1976: “Open your eyes - the world's being turned upside down'" and Mao Tse-tung's order of taking class struggle as the key $\operatorname{link}^{63}$ but also by an intensified debate with the USSR about international class struggle ${ }^{63 a}$.

On the other hand, it is also indicated by this citation that the USSR is considered as the enemy No. 1 by the post-Chou political leadership in Peking. This fact is reducing the flexibility of Chinese foreign policy and most probably will prevent a swing to the extreme position in foreign policy as China of the time of the Cultural Revolution. Therefore, the above described positive Chinese attitude

\footnotetext{
57 Peking Rundschau, no 40, October 9, 1973, p. 13.

58 Peking Rundschau, no 41 , October 15,1974 , p. 10.

59 Peking Rundschau, no 40, October 7,1975, p. 10; and most recently: Peking Rundschau, no 42, October 18, 1976 , p. 15.

60 See Gerd Kaminski, “Neutralität - eine Chance für die Staaten Südostasiens”, pp. 88-89.

61 Peking Rundschau, no 40, October 7, 1975, p. 10.

62 Chinese Literature, no 3,1976, p. 6.

63 Peking Rundschau, no 6, February 10, 1976, pp. 5-8.

63a Hsinhua (London) Daily Bulletin, no 6600, April 21, pp. 4-5.
} 
towards neutrality has a good chance of survival; because it suits exactly into the unchanged scheme of the Chinese struggle against Soviet hegemonism.

(B) Will the Chinese attitude towards Neutrality be influenced by a more Revolutionary phase of Chinese Foreign Policy?

One might be seduced to think so if one watches the use of terminology by Chinese leaders and the Chinese press versus Laos since the proclamation of the People's Democratic Republic of Laos. In a message of the Chinese party and state Leaders greeting the founding of the new People's Republic they expressed that they fell sure that:

"... Under the leadership of the People's Revolutionary Party of Laos, the Lao people with their tradition of revolutionary struggle will build Laos into an independent, democratic and prosperous country by persisting in independence and self-reliance and continously supporting difficulties in their way ahead. We wish that the revolutionary friendship between the Chinese and Lao people's grows in strength and develops steadily ${ }^{64}$."

Between "independent and democratic" in the Chinese declaration about Laos before has been always the word "neutral" and also later Chinese speeches and press comments proved that the ommission cannot have been accidental. It has also been stressed by Premier Hua Guo-feng on the occasion of the visit of Lao Party and Government delegation on March 15, 1976:

"After the establishment of the People's Democratic Republic of Laos, the Lao people still face the arduous task of defending and building the country. We Laos the Lao people who have been tempered and tested in protracted revolutionary struggle, upholding independence and self reliance will remove obstacles, overcome all the difficulties in their way of advance and build Laos into a peaceful, independent (here "neutral" is omitted - reference by me) democratic, unified, prosperous and socially progressive country ${ }^{65}$."

Later in the text after the significant depiction of the "continuation and deepening of the Great Proletarian Cultural Revolution" now going on in China Hua concludes:

"The common struggle against imperialism agression has bound our own people even more closely66."

A similar version can be found in the respective editorial of Renmin Ribao from March 15, 1976, "Warm Wellcome to Lao Party and Government delegation." After stating that "The founding of the Lao People's Democratic Republic last December opened a new chapter in the history of Laos ${ }^{67}$ " the Chinese paper asserted:

"The Lao people are full of confidence in realizing the resolution adopted by the All-Lao Congress of People's Representatives and the administrative policies of the Government of the Republic, and are fighting for a peaceful, independent (here "neutral" is ommitted - reference by me), democratic, unified and prosperous Laos with social progress...

\footnotetext{
64 Hsinhua (London), Daily Bulletin, no 6467, December 5, 1975, p. 2

65 Hsinhua (London), Daily Bulletin, no 6566, March 16, 1976, p. 4.

66 Ibid.

67 Hsinhua (London), Daily Bulletin, no 6565, March 15, 1976, p. 2.
} 
We are convinced that the Lao people will surely overcome the difficulties in their advance and score new and greater victories as long as they adhere to the principle of independence and self-reliance and wage a hard struggle ${ }^{68}$."

Without knowing the context of China's present situation in world-politics one could be inclined to say, that now after the communists have taken over all the power in Laos not only defacto but also dejure China has dropped her mask of benevolent attitude towards the status of Permanent Neutrality and has limited Sino-Laotian relations to the solidarity of Proletarian Internationalism. But a more careful analysis may show that it is not so.

The Chinese experts on international law, who have granted interviews to the author of this study in 1972 expressed the view that the people of Laos has to decide itself whether it considers its Permanent Neutrality annulled by foreign intervention or not. We have seen from a previous quotation, that the Peking Government, even after the communist military victory in Laos has been ready to accept and praise Laotian neutrality. If China has stopped mentioning Laotian neutrality after the proclamation of the People's Democratic Republic of Laos (expressively), the reason need not necessarily lie in the fact that China has stopped valuing this neighbour states' status of Permanent Neutrality.

It is quite possible that the Government of Laos is not too fond of limiting its own mobility in foreign politics by talking about its status created by the Geneva Agreements. Most probably it is not keen to give any room to interference by the guarantee powers and besides it might think of getting this way a more advantagous position in respect to its big Chinese neighbour. In the official statements from the new People's Democratic Republic of Laos we miss any reference to neutrality but find the same formulas in statements of Laotian leaders which we could find in the above quoted Chinese statements. The only difference is that the Laotian statements were earlier. On December 6, 1975 the Premier of the People's Democratic Republic of Laos Kaysone Phomvihane gave a political report at the Lao National Congress of People's Representative about the present situation and future tasks in Laos, and asserted that Laos will advance rapidly and strongly on the path of: "independence, democracy, unity, prosperity and strength ... to aim at the achievement of a peaceful, independent, democratic, united and prosperous Laos69." At a celebration on the occasion of the founding of the People's Republic, Vice-Premier Phoumi Vongvichit declared on December 9, 1975: "This historic victory has brought the revolution in Laos to a new stage and created favourable conditions for the Lao people to consolidate their right of independence and build Laos into a peaceful, independent, democratic, unified, prosperous and socially progressive country ${ }^{70}$." On January 6, 1976 in celebrating the 20th Anniversary of Lao Patriotic Front, the press and radio of Laos took up the slogan "we shall certainly be able to march towards the lofty goal - that is, building a peaceful, independent, democratic, unified, prosperous and socially progressive Laos" ${ }^{71}$. 
Thus it becomes quite clear that Peking has been following the Laotian regulation of terminology. If it is so the conclusion that the impetus about keeping quiet about Laotian Permanent Neutrality came from the Chinese side does not hold water.

If we now examine Chinese official declarations and comments on Laos carefully once more we will find that China by using formulations like "persisting in independence and self-reliance" (greeting address of the Chinese leaders on the occasion of the founding of the People's Democratic Republic of Laos), "upholding independence and self-reliance" (Premier Hua Guo-feng on the occasion of the first visit of the new Laotian People's Republic leader's in China), "We are convinced that the Lao people will surely overcome the difficulties in their advance and score new and greater victories so long as they adhere to the principle of independence and self-reliance ..." (Editorial of Renmin Ribao from March 15, 1976) has shown much concern that Laos does not get into the sphere of influence of any big power.

The basic principles of Chinese foreign policy have made China to up-hold two standpoints in the case of Laos: First, the independence and sovereignty is to be respected especially in relation to a small state. Therefore, China did not show objection when Laos hinted that it does not want to be reminded of the Geneva statements. Secondly: in return for China's scrupulous respect with regard to Laotian independence, Laos had to keep to a neutral course even if out of tactical reasons other terms had later to be used for that.

That means that the Chinese scheme of being surrounded by neutral and also communist-neutral-states has still kept its validity in spite of switching to other terms in the case of Laos. That this Chinese scheme can count on a positive echo in the case of Laos can be proved by quoting once more the political report of the Laotian Premier which contained the phrase: "Guarantee permanent independence, sovereignty unity and territorial integrity of the country ${ }^{72}$." The description of a neutral country without making use of the special term.

These views find support by throwing a glance on Chinese-Cambodian relations. China has never ceased praising Cambodias neutral course which is not in a similar delicate position like Laos in respect to international agreements. For instance, very recently on April 17, Renmin Ribao carried an editorial on the occasion of the first anniversary of the communist victory in Cambodia calling Cambodia an "independent, peaceful, neutral, non-aligned, sovereign and democratic state" which in international afairs "has constantly pursued the policy of independence, peace, neutrality and non-alignment and actively supported the just struggle of the people of various countries ${ }^{73}$ ". Cambodia did not hesitate to give a positive response to Peking's expectations and the new communist leaders even wrote into the new communist Constitution that the entire Cambodian people desire an "independent, unified, peaceful, neutral, non-aligned, sovereign Cambodia enjoying territorial integrity". (The Preamble, Article 1.) It is "committed to a policy of independence, peace, neutrality and non-alignment, permitting absolutely no foreign country to have military bases on its territory and providing for absolute struggle against all forms of outside interference in its internal affairs, and absolute

72 See under 69.

73 Hsinhua (London), Daily Bulletin, no 6597, April 17, 1976, p. 13. 
struggle against all forms of subversion and aggression against Cambodia from outside ..." (Art. 21) ${ }^{74}$. This position was reaffirmed by the Cambodian President Khieu Samphan at the first plenary session of the First People's Congress of Cambodia ${ }^{75}$.

In respect of the plans for Neutralisation of Southeast Asia, China also under the new Premier Hua Guo-feng and during a period of intensified class struggle, has adhered to its previous positive attitude. China has dedicated friendly presscomments to the conferences of ASEAN countries dealing with the neutralityplan ${ }^{76}$, and very recently has again spoken strongly for a proper realisation of the Southeast Asian states' efforts to achieve neutrality accusing the USSR of playing tricks on those countries and trying to "sell them fish-eyes for pearls" by falsifying the real and accepted plans for neutrality in Southeast Asia ${ }^{77}$.

Altogether this means that China's positive attitude towards neutrality has remained unchanged. Also during the time when Deng Xiao-ping, who was mainly entrusted with the execution of foreign policy for the mortally sick Chou En-Lai, has been replaced, China's present international position marked by the anti-hegemonism struggle especially against the USSR does not permit any substantial changes in China's attitude towards the neutrals.

\section{(C) Recent Clarification of Chinese Views on Armed Neutrality:}

Under the influence of anti-hegemonialism, China not only kept to her old position of favouring neutrality but even most recently has made an important further clarification in respect to armed neutrality.

Still nowadays the Defacto Neutrality of many neutralist states differs from that of Defacto Neutrals in the strict sense (like i. e. Sweden) especially with regard to national defence. Many neutralists pay little attention to safeguarding their independence by military means and have met relevant Chinese objections. Certainly the first and oldest Chinese-communist-point of view regarding Neutrality has to stress that small neutralist states need not have the protection of any military bloc. This position has been taken in respect to US-statements in 1956 expressing the view that Cambodia is a small country and not in a position to hold its own against the threat of communism ${ }^{78}$, and has been reconfirmed - see quotations above - on the occasion of the Geneva-conference on Laos in 1961-62. Yet especially at Geneva, China has shown to be rather carefree about the way a neutral state would protect itself against foreign intervention and aggression, and represented adamantly the standpoint that this would be exclusively a matter of the neutral state's internal affairs. According to the Chinese opinion of that time, the neutrals could deal with the problem of their national defence in whatever manner the neutrals thought fit.

The Chinese position that neutrals should not be protected from outside is of course still valid and has gained even more importance by the Chinese fight against the Soviet plans for an Asian Collective Security System. However, the Chinese have no longer remained indifferent to the question how neutrals secure their independence. Therefore, China has criticised one point of the resolution

74 Summary of World Broadcasts, Part 3, The Far East, January 7, 1976, FE/5100/B/3-5.

75 Hsinhua (London), Daily Bulletin, April 17, p. 23.

76 Hsinhua (London), Daily Bulletin, no 6533, February 12, 1976, p. 6; no 6550, February 29,1976 , p. 11.

77 Peking Rundschau, no 16, April 20, 1976, p. 25.

78 People's China, no 9, May 1, 1956, p. 44. 
of the Group of 77 developing countries at the UNCTAD-Conference in 1972, which demanded disarmament in favour of financial support for the economic and social progress of the developing countries. The Chinese delegation presented the view that in the region of hegemonial struggle of the two superpowers, the problem of disarmament sould not be solved satisfactorly and that the developing countries should rely on their own strength ${ }^{79}$. Also on other occasions, China has emphasized that small and weak states should neglect their military national defence only after the superpowers have laid down their $\operatorname{arms}^{80}$.

China's leadership has abstained from exercising pressure on the neutrals in order to make her standpoint accepted, but she did not fail to show her vivid interest in this point by praising the efforts for national defence undertaken by neutral states or to raise this problem in talks with guests from neutral states. So for instance Premier Chou En-lai showed his concern in 1972 about Austrian military national defence at a talk with the Austrian Minister for Trade and Commerce Josef Staribacher and Chinese Foreign Minister Qiao Guan-hua expressed his worries about Austrian security to the leader of the delegation of the Austrian Institute for China Research, Dr. Alois Nock, in $1975^{83}$.

Meanwhile China's anti-hegemonial struggle has put more drive behind the Chinese arguments. In the issue of 15 April 1976, the "Peking Rundschau" published an article with the title: "Can small countries guarantee their security by themselves." The article strongly asserted that they can and indirectly rejected excuses for neglecting national defence by making references to the overwhelming strength of the superpowers ${ }^{84}$.

It seems that in the course of this development, China has most recently changed her legal position with regard to armed neutrality of permanent neutral states. It may be recalled that the Chinese experts on international law, told the author of this study in 1972, that the way how to manage its national defence is the permanent neutral states sovereign decision. Although not expressing it openly, China in the meantime seems to have come to the conviction that the permanent neutral state is legally obliged to make sufficient arrangements for the military defence of its neutrality and independence. This one can see from an article about permanent neutral Switzerland contained in the Peking Rundschau No. 15 cited above which carries the significant title: "A small country must be prepared as well85." This new development in Chinese attitude towards the armament of permanent neutral states becomes still more clear if one adds a quotation from a Hsinhua feature dated from March 12, 1976, a story about Austrian vigilance against aggression. Since China seems to be especially worried about the Austrian military strength, the Chinese opinion found more pointed expression. The composition of this story follows the old pattern of recommending Chinese views by citing suitable voices from the press of other countries and reporting similar standpoints of decision-makers there. Thus Hsinhua in citing Austrian newspapers,

\footnotetext{
79 Peking Rundschau, no 22, June 6, 1972, p. 17.

80 Peking Rundschau, no 49, December 7, 1971, pp. 14-16; no 44, November 7, 1972, pp. $20-22$.

81 See "Head of Swiss Military Department stresses vigilance and defence", Hsinhua (London), Daily Bulletin, February 13, 1973, p. 6.

82 See Josef Staribacher, "Eindrücke von Wirtschaft und Politik Chinas", in: China-Report, no 9/10,

83 Alois Mock, "Chinesischer Kommunismus - 'Mit Konsequenz und Härte’”, p. 37.

84 pp. $17-18$.

85 p. 19.
} 
carried Austrian Federal Chancellor Bruno Kreisky and Austrian Commander-inChief General Emil Spanocchi by selecting sentences which go well with the Chinese wish of seeing militarily well prepared permanent neutral states. But the sub-titles were made by Hsinhua, which is not just a News Agency but a high political Chinese institution of great importance working directly for the Chinese Government. One of the sub-titles contains the clear Chinese demand:

"Neutrality must be safeguarded by force ${ }^{86}$."

\section{Conclusion:}

Summarizing the Chinese practice towards neutral states, one may say that after the mid-fifties there has been an increasing positive attitude which has been only partly and temporarly weakened around the time of the Cultural Revolution. Due to China's anti-hegemonial struggle, Neutrality has still gained more value for Chinese politics and one may dare to predict that in future China will show still more political and possibly also scientific engagement with the different forms and aspects of neutrality.

86 See "Chronik of Austrian Chinese relations", China-Report, no 26/27, 1975/76, p. 50. 


\title{
New China Welcomes Neutrality
}

\author{
By Gerd Kaminski
}

Chinese practice and doctrine show that at the very beginning the Chinese attitude towards neutrality was rather hostile. The change came when the USSR began to favour neutrality. It was their Soviet-influenced course and soon the idea that in this way they could improve their own international position which made the Chinese begin to show sympathy to neutral states. Mao Tse-tung's article "On People's Democratic Dictatorship" was released in a new version in which the previous general condemnation of neutrality was ommitted.

The obstacles for favouring neutrality had been removed. But this did'nt mean however that the Chinese immediately started a penetrating research. They did'nt present clearcut views on neutrality. Their knowledge and conception of neutrality were vague. (This has been confirmed by the Swedish Ambassador Lennart Petri after the mainpart of this script has been finished. Lennart Petri granted an interview to the author on Sept. 13, 1976 and stated clearly that during the fifties and most of the sixties the Chinese appreciated the fact that neutrals did'nt join the military blocs and other aspects favourable to them but did'nt show thorough interest in the complexity of a neutral state's legal status and hardly even used the word "neutral".) During the time of the Cultural Revolution the Chinese tried hard to reform neutrality in their favour and only the permanent neutral states remained comparatively unmolested.

The Sino-Soviet rift has encouraged a more thorough going occupation of Chinese practitioners and scholars with neutrality and has broadened the field of application. The Chinese became more outspoken about the problems of neutrality and they seem to compete against the Soviet model of satellite states with a model of a big communist power surrounded by neutral - among them also communist states. Neither the influence of criticizing Deng nor a relaxation of Sino-Soviet tensions have basically influenced this Chinese attitude basically up till now. The USSR has not yet moved out from the focus of Chinese attacks (Compare the very recent CC-statement of November 2 saying they would "carry out the struggle against modern revisionism through to the end" and they would form a broad front "against the hegemonism of the two superpowers the Soviet Union and the USA” - Hsinhua (London), Daily Bulletin, no 6794, November 3, 1976). Besides, traditional Chinese concepts of international order in Southeast Asia, the ambitions of the peoples in those countries and the lasting disharmony of Chinese interests as regards the USSR make it unlikely that China will readily drop its positive attitude towards neutrality.

\section{Somalia - A Soviet "Satellit Nation" on the Horn of Africa?}

\section{By Volker Matthies}

Recent Western political statements and press commentary has evidenced increasing concern with Soviet aims and strategy in Somalia and in the Indian Ocean. It is assumed that the USSR has achieved significant influence on the politics of Somalia, and that the search for such influence is part of a wide-ranging Soviet 